\title{
Developing a national road traffic safety education program in Iran
}

\author{
Fatemeh Bakhtari Aghdam ${ }^{1,2^{*}}$, Homayoun Sadeghi-Bazargani', Saber Azami-Aghdash³, Alireza Esmaeili',
} Haneieh Panahi ${ }^{5}$, Maryam Khazaee-Pool ${ }^{6,7}$ and Mina Golestani ${ }^{1}$

\begin{abstract}
Background: Education is a pivot included Decade of Action for Road Safety initiative, which has reduced deaths caused by accidents in developed countries. Given the circumstances of each country, a proper education program is necessary. Thus, the aim of this study was to develop the National Road Traffic Safety Education Program (NRTSEP) and reduce Road Traffic Injuries (RTIS).

Methods: This study used a qualitative approach and was conducted in Iran. Data were obtained through sixteen semi-structured in-depth interviews from indifferent road safety and health promotion field experts as well as eleven focus group discussion (FGD) sessions conducted with participants from general population. Inductive qualitative content analysis was used to converge and compare themes through data. The initial pattern of the program was developed and subsequently, the designed program was validated and finalized by two-step Delphi method for the consensus of expert opinion.

Results: The following six main themes emerged from the analysis: target groups, program content, educational methods, instructors, resources and evaluation. The target group consisted of children, youth, parents, teachers, elderly, motorcyclists, cyclists, pedestrians, drivers, driver license applicants, instructors and administrators of driving schools, and specific groups such as the disabled, managers at different levels, and policymakers. The content of the program consisted of 27 items, including traffic laws and regulations, first aid, and medical emergencies. Educational practices and authorities were determined based on the target group and educational content. The most important resources of the program were human force and other cases, which can be managed in case of a lead agency. In the evaluation dimension, the cases such as mortality rate, hospitalization, behavioral changes, and other cases can be considered.
\end{abstract}

Conclusions: The designed program should be implemented for all target groups for road safety promotion. The proper content was provided with proper educational methods and instructors for the target groups. A lead agency is needed to provide the resources and funding to run the program.

Keywords: Traffic safety, Educational program, Traffic behavior, National program

\footnotetext{
* Correspondence: fatemeh.bakhtari@gmail.com

${ }^{1}$ Road Traffic Injury Research Center, Tabriz University of Medical Sciences,

Tabriz, Iran

${ }^{2}$ Department of Health Education \& Promotion, Tabriz University of Medical

Sciences, Tabriz, Iran

Full list of author information is available at the end of the article
}

(c) The Author(s). 2020 Open Access This article is licensed under a Creative Commons Attribution 4.0 International License, which permits use, sharing, adaptation, distribution and reproduction in any medium or format, as long as you give appropriate credit to the original author(s) and the source, provide a link to the Creative Commons licence, and indicate if changes were made. The images or other third party material in this article are included in the article's Creative Commons licence, unless indicated otherwise in a credit line to the material. If material is not included in the article's Creative Commons licence and your intended use is not permitted by statutory regulation or exceeds the permitted use, you will need to obtain permission directly from the copyright holder. To view a copy of this licence, visit http://creativecommons.org/licenses/by/4.0/ The Creative Commons Public Domain Dedication waiver (http://creativecommons.org/publicdomain/zero/1.0/) applies to the data made available in this article, unless otherwise stated in a credit line to the data. 


\section{Background}

In Iran, Road Traffic Injuries (RTIs) are the leading cause of injuries and the second leading cause of death $[1,2]$. In recent years, like most of the developing countries, various interventions and programs have been designed and implemented to reduce RTIs [3-6]. Some of these interventions and programs, including severe treatment with speeding, violations, improvements to vehicle safety, and raised fines and penalties, have a moderate impact on reducing the rate and burden of accidents and some of these interventions, such as increased police funding, security of roads, speed cameras, improved emergency medical care services, and development of transportation infrastructures, especially for the rail transportation, have a slight impact on reduction of traffic accidents [7].

Basically, in road accidents, three factors of human, road, and vehicle are identified as major components, and the quality and quantity of displacements will be affected by these three factors. Human is the most unknown and most important factor in the course of events and, with all the efforts of experts in various sciences, the human reactions in dealing with the events cannot be predicted. Many differences between human beings, including physical, mental, etc., lead to the unknown nature of humans, such that above $70 \%$ of the accidents are attributed to this factor. Although the human factor has its own characteristics in various communities, the human factor, versus other causes, is the most important and difficult part for controlling transportation systems [8]. The analysis of road traffic accidents in Iran suggests that the most common factor involving RTIs could be the human factor. In fact, in traffic crashes in Iran, the human factor alone or along with other factors is often responsible for the majority of traffic accidents $[9,10]$.

The behavior of pedestrians, motorcyclists, and cyclists is a human factor involved in the occurrence of traffic accidents. Due to the role of human factor in the occurrence of accidents, traffic safety education programs are needed to be implemented. The public needs to become aware that the issues of traffic and traffic accidents are vital to their health and safety. In order to reduce traffic injuries policies such as improving the behavior of road users are implemented in countries such as Australia that are pioneering the reduced RTIs and crash fatalities [11] . In Germany, through traffic education in schools, the mortality rate of 19,000 in 1970 s was reduced to 9000 in 1995. In Hamburg, Germany, the deaths caused by accidents became stable around 100 people per year by education in all groups from kindergarten to university and even holding courses for the elderly [12]. Other studied showed that it is necessary to develop road safety education [13, 14].
Different studies in Iran has shown that, despite the implementation of specific laws such as the use of seat belts, the rate of deaths has had small decline without education, demonstrating the need for education and cultural development in the country $[5,15]$.

Therefore, the role of education in reducing traffic accidents is inevitable and the educational programs for the population must be provided and implemented based on the resources and facilities as well as the environmental, economic, political, and cultural conditions of each society.

Considering the human factors for the occurrence of accidents from 2006 to 2016 in Iran, it is concluded that most of these factors can partially be eliminated through education. The major factors, including violation of traffic laws [10, 16-19] and inadequate information [10, 20], are the other cases, in which education can play an important role for changing behaviors. Therefore, it is essential to pay attention to education and cultural development that lead to behavioral changes [21, 22]. Therefore, given the importance of accidents as the second leading cause of death in Iran and the necessity of education with respect to the facilities, and social, cultural, and political contexts of Iranian society. The aim of the present study was to develop the National Traffic Safety Educational Program (NRTSEP) and reduce Road Traffic Injuries (RTIs).

\section{Methods}

As part of the project for developing the National Iranian Road Safety Program, this qualitative study was conducted to develop a National Traffic Safety Educational Program (NRTSEP) in 2019. Semi-structured in-depth interview and focus group discussions (FGD) were used to collect data. Participants in the needs assessment were recruited from of different setting of Tabriz and the traffic experts from Tehran, Mashhad and Shiraz were interviewed. In order to gain a different viewpoint, a purposive sampling method was applied to insure that participants with varying levels of socioeconomic status, age, educational level, job, personal or family accident records, and driving violations were present in this work. At the beginning of interviews, all of participants were informed about the aim of the study.

\section{Focus group discussions (FGD)}

Overall, eleven FGD were conducted with different groups including mothers with young children; parents with students; the elderly; professional drivers; motorcyclists; cyclists; high school students; university students; teachers; offending drivers and elementary students. Sessions were performed in convenient places in reach for all the participants. Each session lasted for about $1 \mathrm{~h}$ 


\section{Semi-structured interviews}

Sixteen semi-structured interviews were conducted with stakeholders and experts on road safety and health promotion in Tabriz, Tehran, Mashhad and Shiraz as well as various organizations with the same conditions a Ministry of Roads and Urban Development, professors and experts of Ministry of Health and Medical Education, police experts, Ministry of Education, forensic medicine, Central Insurance Organization, Iranian Red Crescent Society, National Medical Emergency, Law Enforcement Force, and IRIB. In the selection of participants, the heterogeneous method (participants with the most diversity of various specialties) was used. Sampling was continued until data saturation reached, that is, no new codes were identified in the data. The semistructured interview guide forms were used for the interviews, for which the literature review and opinions of various professors in the fields related to the subject and the research team were used. The interview began with the open-ended questions, such as "Which groups should be taught to reduce traffic accidents?" and continued with these questions "What content should be taught?" and "Who should be taught?". After each question, participants were invited to explain more about what they had reported. The interviews were performed at the expert office's or at a convenient public place. Each interview lasted 60-120 min.

\section{Delphi survey}

Based on the results of previous stages (needs assessment of people and experts) and the opinions of the research team, a primary suitable educational program was formulated. Then, selected educational program were entered into the Delphi survey phase.

\section{Data analysis}

Inductive qualitative content analysis (a bottom-up method to explore the data) was employed based on the Graneheim method to converge and compare themes through participant data. Themes were clustered pursuant to participants' views. In this method, the researcher recognized the themes based on the primary codes and categories. As such, the units of analysis are the entire interviews [23]. Data analysis started throughout the data-gathering process. Each FGD and individual interview was transcribed literally and analyzed before the next FGD or interview was accomplished. Thorough understanding of the data was reached by frequently reading the transcriptions. All transcripts were imported into the MAXQDA software v. 10 which is a method for identifying, analyzing, and reporting themes within the context and is widely used in qualitative data analysis. Data coding was conducted by two of the researchers. Delphi questionnaire was designed using the Likert scale in order to assess the validity and consensus of the formulated educational program and was given to $10 \mathrm{ex}$ perts as expert pannel. After this step, the educational program was modified and became ready to use. The questionnaire consisted of three parts, including a brief introduction to the goals and necessity of the study, a completion guide for form, and forms.

To analyze Delphi method, each of the individuals scored each dimension and area of the educational program in two perspectives of importance (Does this perspective matter and should it be taken into consideration?) and applicability (Is there applicability for this area of the desired dimension?). In this section, the individuals first chose their general idea from three options of "Disagree", "No idea" and "Agree" and, then, based on their previous choices, a score from 7 to 4 was given to each role given the previous option. In the information analysis step of this section, the scores were sorted from right to left. For example, the number 4 in "Disagree" was considered as 7 and number 4 in "Agree" was considered as 9. The number assigned to "No idea" was 5 [24].

\section{Validation}

In order to confirm the validity of the program, the content validity index and modified Kappa were used. For validation in Delphi phase was two rounds of Delphi technique. The first round of the Delphi phase was conducted with 20 experts and scholars of traffic accident. Delphi forms were sent to individuals through emails and 2 weeks were given for completion; after this period, a reminder email was sent again. The second round of Delphi was conducted with 10 people. In this phase, 2 weeks were given to individuals to complete the forms. In this step, due to the high agreement of the first and second phases, the Delphi technique was finished and the program was finalized. Delphi questionnaire consisted of 9 points on the Likert scale and areas with scores above 7 were accepted and areas with mean 4-7 entered the second phase; areas with a score less than 4 were eliminated. The Content Validity Index (CVI) and modified KAPPA were assessed based upon expert perspectives. A minimum cumulative modified KAPPA score of 0.79 is expected to be achieved for the content validation.

\section{Results}

Overall, Six major themes emerged from the analysis forming the six dimensions of NRTSEP, including target group, program content, educational methods, instructors, resources, and evaluation. More information on themes and categories are presented in Table 1 . 
Table 1 Mains themes and categories

\begin{tabular}{|c|c|c|}
\hline Mains themes & Categories (n) & Categories (n) \\
\hline Target groups & $\begin{array}{l}\text { - Preschoolers to university students (153) } \\
\text { - Parents (149) } \\
\text { - Teachers (148) } \\
\text { - Cyclists (141) } \\
\text { - Motorcyclists (126) } \\
\text { - Drivers (124) } \\
\text { - Pedestrians (122) }\end{array}$ & $\begin{array}{l}\text { - Youth (119) } \\
\text { - Elderly (118) } \\
\text { - Driving license applicants, instructors and managers of } \\
\text { driving schools (118) } \\
\text { - Managers at different levels, car manufacturers and } \\
\text { policymakers (117) } \\
\text { - Special groups (disabled, blind, etc.) (90) }\end{array}$ \\
\hline $\begin{array}{l}\text { Program } \\
\text { content }\end{array}$ & $\begin{array}{l}\text { - Education of traffic rules (152) } \\
\text { - Traffic light principles (150) } \\
\text { - Visibility (149) } \\
\text { - Distraction (143) } \\
\text { - Illegal overtaking and speed (137) } \\
\text { - Effect of prescription and non-prescription drugs and alcohol on be- } \\
\text { havior of users (130) } \\
\text { - Places of safe passage (129) } \\
\text { - Benefits of safe passage (124) } \\
\text { - Types of safe passage (124) } \\
\text { - Mutual respect and lack of verbal and nonverbal aggression (123) } \\
\text { - Possible risks while passing (123) } \\
\text { - Observing longitudinal and transverse spacing (123) } \\
\text { - Fatigue and drowsiness (121) }\end{array}$ & $\begin{array}{l}\text { - Increased positive behaviors (121) } \\
\text { - Technical educations (120) } \\
\text { - Clean transport (119) } \\
\text { - Demanding and acquaintance with citizenship rights (119) } \\
\text { - First aid and medical emergencies (119) } \\
\text { - Driving in certain weather conditions (117) } \\
\text { - Seat belt (117) } \\
\text { - Restraint (117) } \\
\text { - Safety helmet (117) } \\
\text { - Diseases and traffic behavior (117) } \\
\text { - Conditional driving (113) } \\
\text { - Right of priority (112) } \\
\text { - Social and religious laws (traffic ethics) (111) } \\
\text { - Sleep disorders (111) }\end{array}$ \\
\hline $\begin{array}{l}\text { Educational } \\
\text { methods }\end{array}$ & $\begin{array}{l}\text { - Audio and visual media (155) } \\
\text { - Practical training (152) } \\
\text { - Courses (144) } \\
\text { - Modeling (138) } \\
\text { - Campaign (127) } \\
\text { - Simulators (122) }\end{array}$ & $\begin{array}{l}\text { - Workshop (19) } \\
\text { - Seminar (17) } \\
\text { - Group discussion (16) } \\
\text { - Social networks (15) } \\
\text { - Material and spiritual fines (14) } \\
\text { - Summary reports (13) }\end{array}$ \\
\hline Instructors & $\begin{array}{l}\text { - TV (163) } \\
\text { - School and university teachers (153) } \\
\text { • instructors of driver's license }\end{array}$ & $\begin{array}{l}\text { centers }(147) \\
\text { - Parents (128) } \\
\text { - Health worker (125) } \\
\text { - Police (120) }\end{array}$ \\
\hline Resources & $\begin{array}{l}\text { - Manpower (29) } \\
\text { - Sufficient budget allocation and financial administrative support } \\
\text { (27) } \\
\text { - Proper technology (19) }\end{array}$ & $\begin{array}{l}\text { - Providing materials and physical space (18) } \\
\text { - National Traffic Document (17) } \\
\text { - Strong monitoring system (12) } \\
\text { - NGOs and charities (11) }\end{array}$ \\
\hline Evaluation & $\begin{array}{l}\text { - Number of accident and deatches (17) } \\
\text { - Observation of traffic behavior before and after educational } \\
\text { program (16) }\end{array}$ & $\begin{array}{l}\text { - Number of hospitalizations (7) } \\
\text { - Air pollution (3) } \\
\text { - Satisfaction of program (1) }\end{array}$ \\
\hline
\end{tabular}

\section{Target groups}

The first theme of NRTSEP was target groups which consisted of 12 groups needing to receive TSEP that included, preschoolers to university students, youth, teachers, parents, elderly, motorcyclists, cyclists, pedestrians, drivers, driving license applicants, instructors and managers of driving schools, Special groups (disabled, blind, etc.), managers at different levels, car manufacturers and policymakers. More information on categories this theme, descriptions and sample of quotations can be found in Table 2.

In sum, we found that children below 18 years of age and students were very important target groups because they will be parents, managers, ... in future.

\section{Program content}

The second theme of NRTSEP was the content of program, which consisted of 27 educational contents that should be taught in different target groups. Table 3 shows the educational content of this program along with an explanations and quotations to select the relevant content.

Overall, it was found that Primary, secondary and tertiary levels of education is given to target group.

\section{Educational methods}

One of the elicited themes in the current study was the educational methods, including 12 categories namely; audio and visual media, practical training, modeling, simulators, Courses, Campaign, workshop, seminar, group discussion, material and spiritual fines, social networks, summary and reports. Table 4 shows the Educational methods of NRTSEP along with descriptions and quotations for selecting relevant training practices.

The majority of participants mentioned TV as the national media that can provide traffic education directly and indirectly for all the target groups. Other training methods must be used based on target group and educational content. 
Table 2 Target groups of the National Traffic Safety Educational Program

\begin{tabular}{|c|c|c|}
\hline Target groups & Description & Quotation \\
\hline $\begin{array}{l}\text { Preschoolers to university } \\
\text { students }\end{array}$ & $\begin{array}{l}\text { Early childhood education was considered important in all } \\
\text { discussions and interviews. Children should see safe behaviors in } \\
\text { the cartoons and other programs in the early ages, because } \\
\text { indirect education greatly affects their behaviors. On the other } \\
\text { hands, a course of traffic must be included from kindergarten to } \\
\text { university. According to the WHO's definition, those below } 18 \text { fall } \\
\text { into the category of children. }\end{array}$ & $\begin{array}{l}\text { "Behavior originates from childhood, becomes } \\
\text { institutionalized, and grows." } \\
\text { "In elementary and secondary schools by age of } \\
\text { children." }\end{array}$ \\
\hline Youth & $\begin{array}{l}\text { They are above } 18 \text { years old who might be students, soldiers, or } \\
\text { involved in other activities. They should receive necessary } \\
\text { education, since they are at the age of getting a driver's license. } \\
\text { On the other hand, post-school education should also continue. }\end{array}$ & $\begin{array}{l}\text { "Today's university student is tomorrow's manager, } \\
\text { employee, or teacher." } \\
\text { "In barracks, dormitories, coffee houses, etc." }\end{array}$ \\
\hline Teachers & $\begin{array}{l}\text { This group is a role model for children and adolescents; } \\
\text { therefore, they should learn a proper traffic behavior and transfer } \\
\text { it to those who make the future. Moreover, teachers as those } \\
\text { who are responsible for traffic safety education must receive } \\
\text { specific training. }\end{array}$ & "Teachers also have a special impact on students." \\
\hline Parents & $\begin{array}{l}\text { Due to the interaction between parents and children and the } \\
\text { impact of their behaviors on each other, all participants and } \\
\text { experts in this study expressed that mothers and fathers should } \\
\text { be trained about safe traffic behaviors and observe these cases in } \\
\text { the daily life. }\end{array}$ & "Parents are the primary role model for children." \\
\hline Elderly & $\begin{array}{l}\text { The WHO classifies the elderly as vulnerable groups who are at a } \\
\text { greater risk due to the reduced motor and cognitive skills. }\end{array}$ & $\begin{array}{l}\text { "He is } 80 \text { years old and driving at the speed of } 180 \\
\mathrm{~km} / \mathrm{h} \text { in a Pride."type of car }\end{array}$ \\
\hline Motorcyclists & $\begin{array}{l}\text { Motorcyclists are the major group at risk of injury and see the } \\
\text { most severe damage in traffic accidents. It is essential that all } \\
\text { motorcyclists receive the required trainings to reduce accidents } \\
\text { as well as injuries during an accident [25]. }\end{array}$ & $\begin{array}{l}\text { "Motorcyclists don't care about the traffic lights" } \\
\text { "He has become a motorcycle messenger down on } \\
\text { the streets." }\end{array}$ \\
\hline Cyclists & $\begin{array}{l}\text { Cycling is a form of physical activity that improves human health. } \\
\text { Moreover, if bikes are more used in the transport system, the air } \\
\text { pollution will be reduced; but, the cycling schools need to be } \\
\text { increased with professional and recreational training periods. }\end{array}$ & $\begin{array}{l}\text { "Safety cases are taught to everyone, including } \\
\text { drivers and cyclists." } \\
\text { "There are a small number of cycling training and } \\
\text { schools." }\end{array}$ \\
\hline Pedestrians & $\begin{array}{l}\text { In Iran, the rate of deaths caused by accidents among } \\
\text { pedestrians in traffic accidents is above 30\% [26]. }\end{array}$ & "The pedestrian doesn't even know where to pass." \\
\hline Drivers & $\begin{array}{l}\text { Given the high rate of accidents, deaths, and injuries caused by } \\
\text { driving in the country, the drivers need to receive special training } \\
\text { programs. }\end{array}$ & $\begin{array}{l}\text { "Driving is not just about parallel parking." } \\
\text { "One is a driver while he has obtained his license } \\
20 \text { years ago." }\end{array}$ \\
\hline $\begin{array}{l}\text { Driving license applicants, } \\
\text { instructors and managers of } \\
\text { driving schools }\end{array}$ & $\begin{array}{l}\text { Driver's license centers give an identity of driver to the } \\
\text { applicants, given that driving is not just about introduction to } \\
\text { driving skills, the correct behaviors and rules related to traffic } \\
\text { both as a driver and as a pedestrian must be taught to the } \\
\text { applicants. For this purpose, the instructors and managers of } \\
\text { driving schools must also receive special training to transfer it to } \\
\text { students. }\end{array}$ & $\begin{array}{l}\text { "Even the instructor doesn't care about the rules, } \\
\text { what do you expect from the leaner?" } \\
\text { "Driver's license is not a right for everyone, it } \\
\text { doesn't mean that everybody is supposed to have } \\
\text { it, it is a competence." }\end{array}$ \\
\hline $\begin{array}{l}\text { Special groups (disabled, blind, } \\
\text { etc.) }\end{array}$ & $\begin{array}{l}\text { The WHO classifies people with disabilities as vulnerable groups } \\
\text { who require specific trainings. }\end{array}$ & $\begin{array}{l}\text { "He is passing through the crossroads in a } \\
\text { wheelchair." }\end{array}$ \\
\hline $\begin{array}{l}\text { Managers at different levels, } \\
\text { car manufacturers and } \\
\text { policymakers }\end{array}$ & $\begin{array}{l}\text { Based on ecological patterns of behavior change, variations at } \\
\text { the scale of policymaking could affect other layers and levels, } \\
\text { and its impact is often greater. If synchronized with other levels, } \\
\text { it will have synergistic effects. Higher sensitivity to the traffic } \\
\text { safety problem is required to make it a priority in all } \\
\text { policymaking. }\end{array}$ & $\begin{array}{l}\text { "It must be sent to all policymakers and mangers." } \\
\text { "First, the managers must be trained." }\end{array}$ \\
\hline
\end{tabular}

\section{Instructors}

The fourth elicited themes in the current study was the instructor, including 6 categories, namely TV, university and school teachers, instructors of driver's license centers, parents, health workers and police.

The most important instructor in the present study was TV as national media that can be successful in promoting traffic behaviors by broadcasting different programs to all target groups. TV can show the lost costs via subtitles by providing the costs and statistics related to blood money, death, and costs of traffic accidents and problems caused by high volumes of traffic, such as respiratory diseases, and provide specific training via special networks such as IRIB Salamat (Specified 


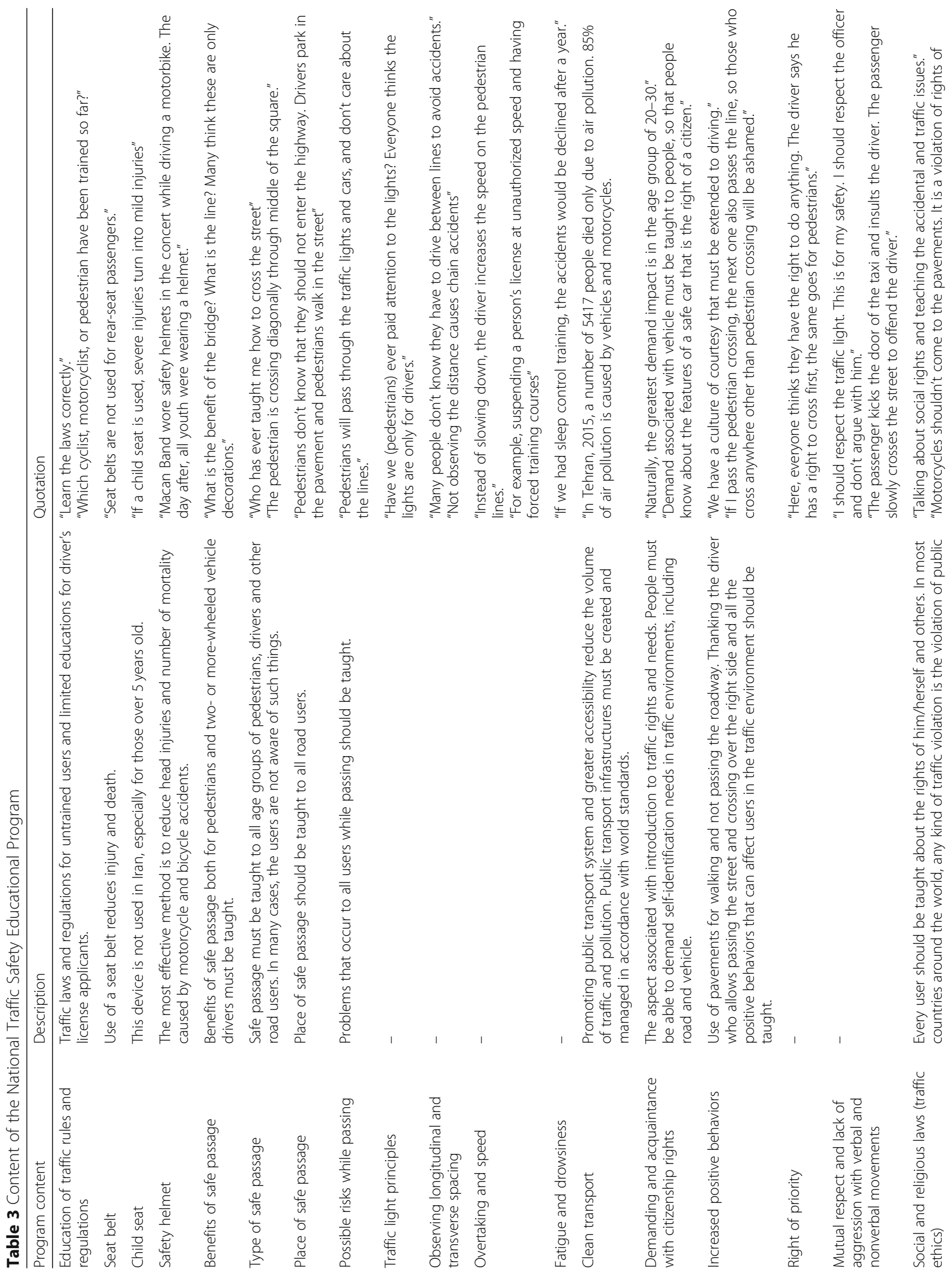




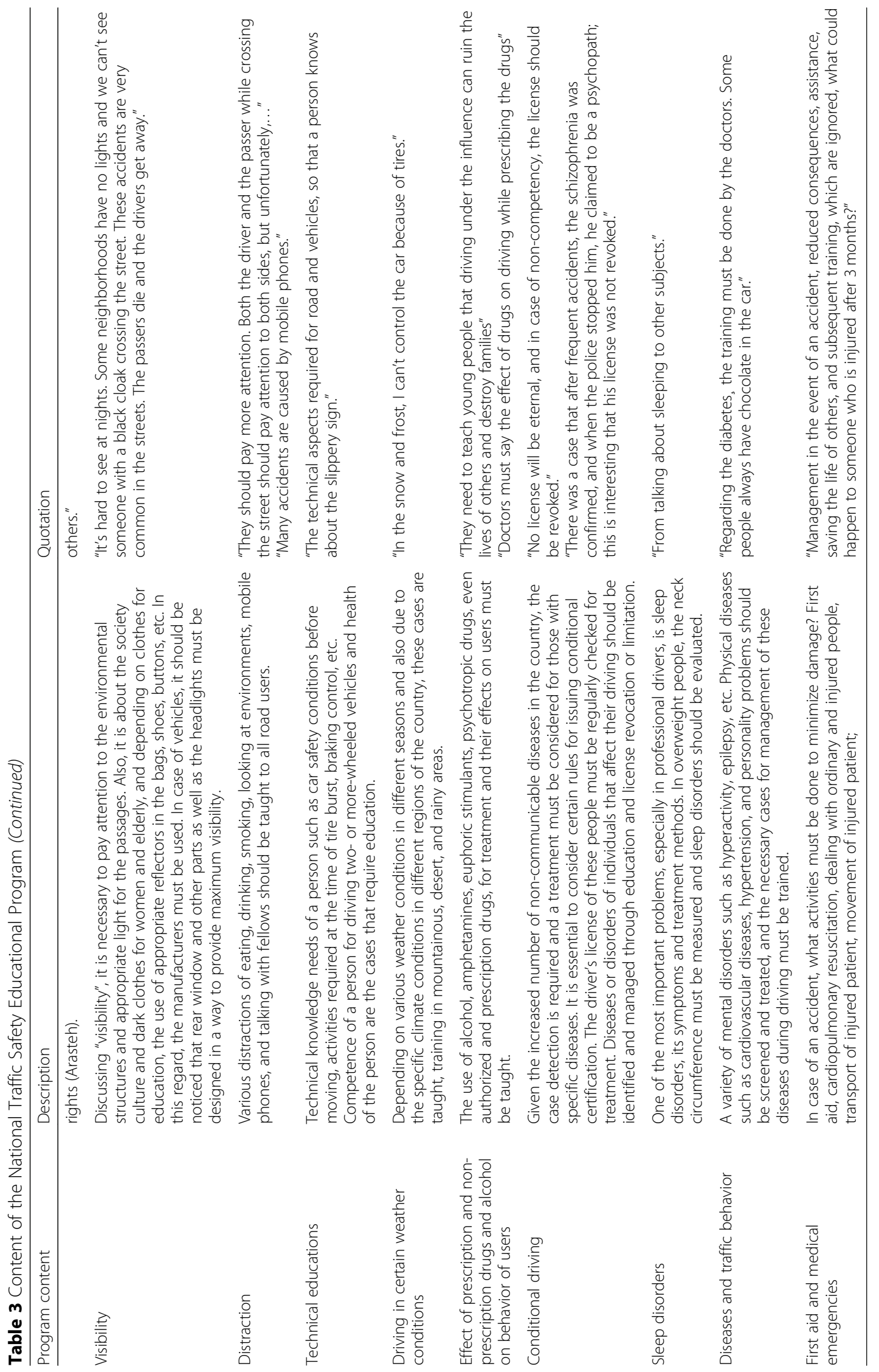




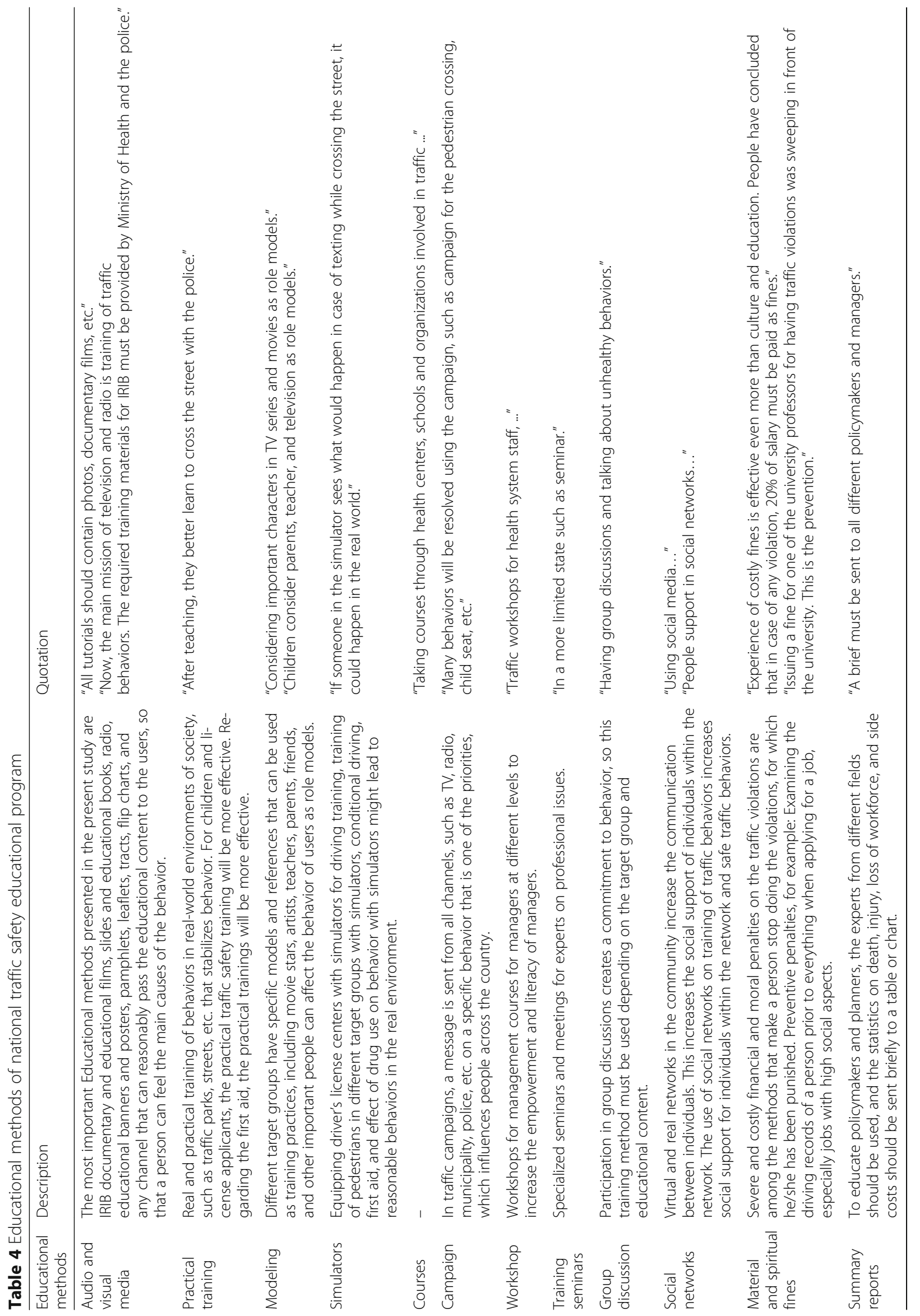


health broadcasting network)for survivors of accidents in the field of consequences, flashbacks, and psychological problems caused by accidents. It can also provide information about books published on traffic accidents and their prevention for different groups from various networks. TV also can show the phone number to report accidents and broadcast the experiences and trainings of successful countries in reducing traffic accidents. It can use the popular characters among the children and adults, such as Sia Saketi and Davood Khatar etc. (Wellknown Iranian cartoon characters) In order to teach safe traffic behaviors and produce documentaries on the lives of accident victims and survivors. Also, a channel known as traffic channel can be established or a great deal of time can be dedicated to the traffic programs in the IRIB Salamat. According to an expert:

"TV has a key role in traffic education".

Another category of instructor was school and university teachers that teach to target groups after being trained. A participant said:

"Students accept more what the teacher says".

. An expert said: "the general academic course on traffic health and safety must be educated through trained teachers in universities for all fields".

Instructors of driver's license centers were another category of instructor theme. As one participant said:

" driving is not just about introduction to driving skills, the correct behaviors and rules related to traffic both as a driver and as a pedestrian must be taught to the applicants through driving schools".

Other educational trustees were trained parents. They can indirectly teach by their right behavior to children.

"Mothers and fathers should be trained about safe traffic behaviors and observe these cases in the daily life".

The other major instructor was Iranian health network rural health workers (called Behvarzes). Traffic behavior, like other healthy behaviors, should be trained trough health workers but the Ministry of Health has neglected it. According to an expert:

"Health centers as the accepted health promotion settings of people can have the important role in traffic behavior education".

Police were another instructor in NRTSEP. An expert said:

"Police can train practical traffic behaviors in different settings such as schools, traffic parks, streets, etc. to establish behavior".

Because of the interaction between the target groups, if all 6 instructors mentioned above are able to educate properly, safety traffic behavior can promote.

\section{Educational resources}

This theme highlighted educational resources containing seven categories as; manpower; sufficient budget allocation and financial administrative support; proper technology; Providing materials and physical space; National Traffic Document; Strong monitoring systems; NGOs and charities.

\section{Manpower}

One of the most important resources required for the program is manpower. According to experts,

"Human resources must be trained with different skills and abilities, because it is at the macro scale across the country."

\section{Sufficient budget allocation and financial administrative support}

The majority of the experts in the present study believed that a lead agency is essential as a way of budgeting and resource management. All organizations must pay a part of their budget for educational contribution. Therefore, the resources are integrated and collected. An organization responsible for traffic at the macro scale According to experts,

"It must be determined who is responsible, the lead agency, traffic police, or the ministry of health? Each ministry should pay its own contribution. All the money should be collected and what has to be done with that money (integration and collection of resources), pooling, etc." Given that the loss of human resources in society causes a severe economic and psychological burden on society, the cost is more effective with larger costs for teaching safe behavior as a prevention level. Another Expert said,

"According to Lougou, if you think that investment in field of education is expensive, you must calculate the costs of ignorance."

Another expert said,

"President Rouhani (Iran president)declared in 2015 that we have 3.5\% negative annual income balance and a mortality figure of 32000 people per year (17000 due to traffic accidents and the rest for air pollution caused by traffic), and GDP of 6.4\%. Therefore, if we prevent the losses caused by accidents, not only 3.5\% negative annual income balance is compensated for, but also we will have 3\% growth."

\section{Proper technology and providing materials and physical space}

Most of experts expressed financial resources are used to provide the budget required for providing educational content with proper methods and multimedia, software programs, applications, electronic content for virtual education, physical space for training, equipment of cycling, motorcycling and driving schools, proper space and simulators, new tools and technologies, and traffic laboratories to create a safe behavior in universities and 
research centers, software and hardware technology for registry of accidents.

\section{National Traffic Document}

National traffic document was the important available resources that can be used for education of policy makers.

\section{Strong monitoring system}

A well-monitored audit structure is also necessary to spend the budget and expense considered in the program to build or modify the infrastructure. According to experts,

"A strong monitoring must be taken into consideration as important resources to prevent abuse of costs for infrastructure in the program."

\section{NGOs and charities}

The advantages of donors, NGOs, insurance, and private companies can be used as program resources. Most of experts mentioned a lead agency can have the key role in resource organization for NRTSEP.

\section{Evaluation}

The last theme of NRTSEP was evaluation, that consisted of five categories namely, Number of accidents and fatalities, Number of hospitalizations, Air pollution, Observation of traffic behavior before and after educational program and Satisfaction about the program.

\section{Discussion}

The purpose of the present study was to develop a national educational program on traffic safety promotion. The importance of education is to the point that one of the pivots of the Decade of Action for Road Safety 2011-2020 is education [27]. One of the important indicators that reduce deaths caused by accidents in developed countries is paying attention to education [12]. In Iran, we have above 17,000 deaths caused by traffic accidents. It is predicted that for each death, 16 cases of accidents lead to hospital admissions and 400 cases require outpatient services [28]. The highest rate of admissions in hospital emergencies is caused by traffic accidents that imposes huge direct and indirect costs on the government and the public and accounts for a major share of annual budget of countries [29].

In order to reduce accidents, hospitalizations, and problems and also to reduce its costs, an educational program is required to promote the user safety behavior given the environmental, economic, political, cultural conditions along with changes in the road network and increased vehicle safety. Based on the results of the study, the national educational program on road traffic safety promotion was designed in 6 dimensions. The main dimensions of this program included, target group, educational program content, teaching method, instructors, resources, and evaluation method.

In the present study of the target group, included 12 groups of preschooler to university students, youth, teachers, parents, elderly, motorcyclists, cyclists, pedestrians, drivers, license applicants, instructors and managers of driving schools, special groups (disabled, pregnant women, blind, etc.), managers at different levels, car manufacturers, and policymakers. In other words, based on the results of the present study, various levels of society should have traffic safety education. Similar to the present study, the PRSE (Permanent Road Safety Education) is continued for learning traffic culture from childhood to the end of life at all levels of society in the successful countries of the world on lowering traffic accidents, such as the Netherlands [12]. Similar to the present study, children's education has been considered because high-risk behaviors are more common in adults and children [30] Childhood, on the other hand, is a very important period for developing behavior [31]. The European Commission also identifies vulnerable groups such as the elderly, pedestrians, disabled people, and all road users as target groups that must be trained [32]. A review study is focused on education of vulnerable groups, such as children, the elderly, pedestrians, bicycles and motorcyclists in the Asia [33]. In Iran, due to the high number of traffic accidents and injuries, all target groups need to be trained. The emphasis of the people and the experts was on education from childhood until the end of life. Knowledge development is one of the pillars of road safety, which can affect drivers' awareness and behavior on the road [13].

The content of the present program consisted of 27 items (Table 1), which is consistent with the educational content used in the world. In the present study, the education of the traffic rules and regulations and safe passage behavior (type of safe passage, place of safe passage, benefits and risks of safe passage) have been mentioned in the educational content for both pedestrians and other users. In Switzerland, the educational content consisted of two main sections: traffic safety, legal traffic behavior, compliance with traffic regulations, and environment [33] and have been successful in traffic education and reduce RTIs. Visibility, reflectors in clothing, bags and shoes, day lights, proper lighting for roads, post-accident care training, public transport to reduce traffic volumes, safe cycling and its infrastructures, education of managers at different levels, car manufacturers, and policymakers to improve vehicle safety, improvement of transport system, modification of road network structure, and greater vehicle safety, overtaking and speed, pedestrian safety, and place of safe passage, were the results of the present study that WHO has also 
pointed out [34]. Wearing seat belts, safety helmets, observing authorized driving speed, alcohol use, and first aid were the educational content obtained in the present study, Permanent education of theirs can reduce of RTIs [35-38].

In the present study, the educational methods included audio-visual media, practical education, role modeling, simulators, taking courses, campaigns, workshops, educational seminars, group discussions, social networks, financial and moral penalties, and brief reports, which is similar to the review study conducted by Jamaludin et al. [39]. The teaching methods in schools at Netherlands are done using traffic guides and distribution of books, pamphlets, films and CDs. In Germany, the traffic safety education is done via film and slides, websites, book distribution, simulators, games, practical street tours [12], and workshops [36]. The safety and traffic training course will be held in Iranian universities from 2018. This course was conducted as a national preliminary study in four stages. The results showed that before participating in the training courses, the level of knowledge of student traffic was low. Studies have also shown that "pedestrian safety" and "first aid" were the most useful and practical issues [40]. The educational method can varied based on target group and type of content. For example, in the driver license applicants, some behaviors such as the impact of using a mobile phone while driving can be simulated, so the person can somehow understand the reality. In the present study, educational instructors included TV programs, schools and university teachers, parents, teachers of driving schools, seminary, health workers, and police experts, and a part of which has been noted in a study conducted by Mark Lee and Al-Mansour [35]. Peden has also considered the health workers as educational authorities [36]. Mütze and Dobbeleer reported that in $81 \%$ of the states, the Ministry of Education is responsible for safety and traffic education, in collaboration with Minister of Transport, police, and government and nongovernmental agencies. In England and Wales, the local highway authorities are responsible for road safety education [37].

The participants of the present study considered IRIB and its programs as the most important educational authorities, which directly and indirectly affect the education and promotion of safe traffic behavior, and then, there are the teachers trained in schools who are responsible for education of students. In this study, the resources were human resources, appropriate technology, adequate budgeting and financial support, materials and physical space, national traffic document, strong monitoring system, and NGOs. In Turkey, Kenya and Egypt, NGOs have been involved in traffic safety promotion programs [36]. The necessary resources and training budget in the Netherlands are provided by the sustainable budget of traffic safety education. In Germany, the books and pamphlets for traffic courses are provided by the Traffic Education Association and are given to teachers for training. German educational resources are so rich that could have reduced the death rate of pedestrian children by almost 20 times. Since 1947 , the legal authority of road safety has been given to local authorities in England, and by hiring road safety officers, they provide the education costs of the road safety program. The Swedish National Institute of Transport and Research, along with other transport and training institutions, develop educational programs and provide resources to the education target group [12].

Experts participating in the present study stated that the resources will be managed in case of a leader agency in the field of traffic in the country. This agency can monitor and evaluate the organizations' function, lead the policymaking, and manage the resources, and therefore, the problem of inter sectional cooperation that wastes the resources will be resolved. In countries that have managed to reduce the number of injuries caused by traffic accidents, an agency or organization with sufficient authority is responsible for plans and activities to reduce traffic accidents and other organizations should have an interaction and collaboration with this agency $[41,42]$.

The results of the present study showed that the educational program should be evaluated. For evaluation of program, the items included the frequency of deaths caused by traffic accidents, number of accidents and hospitalizations before and after training program, frequency of safe and non-safe behaviors before and after training program, satisfaction with program, and air pollution. Some programs have evaluated traffic behaviors after educational programs [43]. Some of the programs have also focused on quality of program and subsequent behavior changes [37]. Some studies have investigated the mediating variables, such as knowledge, attitude, and safe behavior [44]. In the Netherlands, an annual evaluation is conducted by research institutes on the impact of traffic training on behavior of students and parents, and the headings and instructions are constantly being revised, varied, resolved, and modified. All educational products and sustainable education plans of road safety are also evaluated. In German schools, in case of traffic accidents for a student who is unfamiliar with traffic regulations, the relevant teacher is responsible. At the end of each year, the students are tested so both the student and teacher are evaluated [12].

The present designed program must be implemented, and during implementation at various levels, the level of learning, impact on society, and long-term investment must be evaluated. 


\section{Strengths and weaknesses of the study}

Currently, the educational programs are implemented in a dispersed and island manner for some groups, but these programs need to be implemented continuously to reduce the number of accidents, deaths and injuries. This is the first program that was conducted as a needs assessment of people in different groups and was validated by Iranian experts.

The weakness of the present study was that only residents of Tabriz were used in needs assessment and people from other parts of the country were not surveyed. The research team hopes that this program can be implemented, and changes in traffic behavior followed by a decrease in death rate can be seen.

\section{Conclusion}

According to the people and professionals, Ministry of Education plays a key role in education and institutionalization of traffic behaviors, and the curriculum on traffic safety should be included in all grades and educational levels of students based on their age and are taught in a practical manner. Due to a high interaction between parents and children, the education of children will affect parents. Moreover, the television and radio should also provide the traffic education so that this interaction can continue to reach a safe traffic behavior. After the Ministry of Education and the media, the driver license centers are particularly important in education and promotion of safe behaviors. According to both groups of people and professionals, the education of managers at different levels and policymakers in establishing and modifying infrastructure and adopting and reforming laws are critical in the national educational program on traffic safety promotion. The experts particularly emphasized the need for a leader agency to manage the traffic accidents.

\section{Abbreviations}

NRTSEP: National traffic safety educational program; RTI: Road traffic injuries; FGD: Focus group discussions; IRIB: Islamic Republic of Iran broadcasting

\section{Acknowledgments}

We would like to thank all the participants for their contributions to the present study as well as the specialists without whose support the present study would not have been completed.

\section{Authors' contributions \\ FBA and HSB are the main investigator and were involved in the study Design. FBA, SAA and HP were also involved in the data collection and analysis. AE, MKP and MG contributed to the theory and design of the manuscript, and critically revised the final article. All authors read and approved the final manuscript.}

\section{Funding}

Traffic Accident Management and Prevention Research Center of Tabriz University of Medical Sciences provided funding sources for this study. The funding bodies had no involvement in the study design, data collection, analysis and interpretation of data or the decision to submit for publication.

\section{Availability of data and materials}

The datasets generated and/or analyzed during the current study are not public available in order to protect the participants anonymit, but they are available from the corresponding author on reasonable request.

\section{Ethics approval and consent to participate}

Participants completed informed written consent. All interviews were audiotape and transcribed with participant's consent. This article is part of a major project, "National Document on Traffic Health and Safety in the Islamic Republic of Iran", which has been assigned to Traffic Accident Management and Prevention Research Center of Tabriz University of Medical Sciences from the planning and Budget Organization. Dr. Homayoun Sadeghi Bazargan is the principal executer and scientific secretary of this project and Dr. Mohammad Hossein Soumi is responsible of the project. The study received ethical approval from the Ethics Committee of Tabriz University of Medical Sciences (NO:IR.TBZMED.REC.1397.1009).

\section{Consent for publication}

Not applicable.

\section{Competing interests}

The authors declare that they have no competing interests.

\section{Author details}

${ }^{1}$ Road Traffic Injury Research Center, Tabriz University of Medical Sciences, Tabriz, Iran. ${ }^{2}$ Department of Health Education \& Promotion, Tabriz University of Medical Sciences, Tabriz, Iran. ${ }^{3}$ Tabriz Health Services Management Research Center, Health Management and Safety Promotion Research Institute, Tabriz University of Medical Sciences, Tabriz, Iran. ${ }^{4}$ HRM \& traffic safety Department, Tehran University of police, Tehran, Iran. ${ }^{5}$ Department of Promoting \& Rural Development, Master of Science in Agricultural Engineering the tendency for rural development, Tabriz University, Tabriz, Iran. ${ }^{6}$ Department of Public Health, School of Public Health, Mazandaran University of Medical Sciences, Sari, Iran. ${ }^{7}$ Health Sciences Research Center, Addiction Research Institutes, Mazandaran University of Medical Sciences, Sari, Iran.

Received: 24 March 2020 Accepted: 18 June 2020

Published online: 06 July 2020

\section{References}

1. Chaney RA, Kim C. Characterizing bicycle collisions by neighborhood in a large Midwestern city. Health Promot Pract. 2014;15(2):232-42.

2. Tin ST, Woodward A, Ameratunga S. The role of multilevel factors in geographic differences in bicycle crash risk: a prospective cohort study. Environ Health. 2013;12(1):106.

3. Khorasani-Zavareh D, Shoar S, Saadat S. Antilock braking system effectiveness in prevention of road traffic crashes in Iran. BMC Public Health. 2013;13(1):439.

4. Soori H, Ainy E, Movahedinejad A, Mahfozphoor S, Vafaee R, Hatamabadi $H$, et al. A practical model of political mapping in road traffic injury in Iran in 2008. Hakim Res J. 2009:12(3):1-9.

5. Ainy E, Soori H, Montazeri A, Omidvari S, Jahangiree AC, Shiran G. The role of pupils liaisons on traffic penalties and road traffic injuries in Iran. Inj Prev. 2010;16(Suppl 1):A17-A.

6. Soori H, Royanian M, Zali AR, Movahedinejad A. Study of changes on road traffic injury rates, before and after of four interventions by Iran traffic police. Pejouhandeh J. 2009;14(1):15-20.

7. Azami-Aghdash S, Gorji HA, Shabaninejad H, Sadeghi-Bazargani H. Policy analysis of road traffic injury prevention in Iran. Electron Physician. 2017;9(1): 3630

8. Sharma B. Preventing injuries by addressing human factors in causation of road traffic crashes. J Punjab Acad Forensic Med Toxicol. 2007:7(2):20-8.

9. Sadeghian F, Khosravi A, Emamian M, Younesian R. The pattern of road traffic injuries and related factors in Shahrood, Iran. Payesh Health Monit. 2008;7(3):225-33.

10. Charkazi A, Esmaeili A, Garkaz G, Qoreishi Z, Gerey S, Nazari S. Epidemiologic survey of road traffic accidents in patients admitted in emergency department of Alejalil Hospital in Aq-Qala city, Golestan province. 2012.

11. Krantz DH, Kunreuther H. Goals and plans in decision making. Judgm Decis Mak. 2007;2(3):137. 
12. Arasteh HR, Behrangi MR, Naveebrahim AR, Rafiee H. Developing traffic order \& safety: examining traffic training in six European countries. Order and security guards journal. 2011;3(4):111-39.

13. Alonso F, Esteban C, Useche S, Colomer N. Effect of road safety education on road risky behaviors of Spanish children and adolescents: findings from a national study. Int J Environ Res Public Health. 2018;15(12):2828.

14. Alonso Plá FM, Esteban Martínez C, Useche SA, Manso Pérez V. Determinants and stakeholders influencing children's road safety education. Int J Elementary Educ, 2016, vol 5, num 6, p 63-68. 2016.

15. Bazargani HS, Saadati M, Rezapour R, Abedi L. Determinants and barriers of helmet use in Iranian motorcyclists: a systematic review. J Inj Violence Res. 2017;9(1):61

16. Khan AA, Fatmi Z. Strategies for prevention of road traffic injuries (RTIs) in Pakistan: situational analysis. J Coll Phys Surgeons Pakakistan. 2014;24(5):356.

17. Salimi J, Zareei M. Trauma: an epidemiological study from a single institute in Ahvaz, Iran. 2008.

18. Baghiani Moghadam M, Halvany G, Ehramposh M. A survey on personality of motor cycle riders involved in accidents. J Mazandaran Univ Med Sci. 2006;16(51):69-75.

19. Ainy $\mathrm{E}$, Soori $\mathrm{H}$, Ganjali M, Baghfalaki T. Eliciting road traffic injuries cost among Iranian drivers' public vehicles using willingness to pay method. Int J Crit IIIn Inj Sci. 2015;5(2):108.

20. Torabi A, Tarahi M, Mahmoudi GA. Epidemiology of motorcycle accident in Khoramabad, Iran. Payesh. 2009;8(3):253-62.

21. Mohan D, Tiwari G, Khayesi M, Nafukho FM. Road Traffic Injury Prevention: Training manual (Publication. Retrieved 17-08-2007, from World Health Organization and Indian Institute of Technology Delhi. 2006. http:// whqlibdoc.who.int/publications/2006/9241546751_eng.pdf.

22. Assailly J. Road safety education: what works? Patient Educ Couns. 2017;100: S24-S9.

23. Bengtsson M. How to plan and perform a qualitative study using content analysis. NursingPlus Open. 2016;2:8-14.

24. Azami-Aghdash S, Tabrizi JS, Sadeghi-Bazargani H, Hajebrahimi S, NaghaviBehzad M. Developing performance indicators for clinical governance in dimensions of risk management and clinical effectiveness. Int J Qual Health Care. 2015;27(2):110-6.

25. Brazinova A, Majdan M. Road traffic mortality in the Slovak Republic in 1996-2014. Traffic Inj prev. 2016;17(7):692-8.

26. Rahimi A, Kazemi M, Movaghari $H$. An accident prediction model for fatalities in rural areas. Traffic Manage Stud. 2012;6(23):29-46.

27. Bliss T, Breen J. Meeting the management challenges of the decade of action for road safety. IATSS Res. 2012;35(2):48-55.

28. Roy N, Murlidhar V, Chowdhury R, Patil SB, Supe PA, Vaishnav PD, et al. Where there are no emergency medical services-prehospital care for the injured in Mumbai, India. Prehosp Disaster Med. 2010;25(2):145-51.

29. Zavareh DK, Bohm K, Khankeh H, Talebian MT, Mohammadi R, Bigdeli $M$, et al. Why should being visible on the road? A challenge to prevent road traffic injuries among pedestrians in Iran. J Inj Violence Res. 2015; 7(2):93-4.

30. Alonso F, Esteban C, Useche SA, Manso V. Analysis of the state and development of road safety education in Spanish higher education institutions. High Educ Res. 2016;1(1):10-8.

31. Aghdam FB, Ahmadzadeh S, Hassanalizadeh Z, Ebrahimi F, Sabzmakan L, Javadivala $Z$. The effect of maternal employment on the elementary and junior high school students' mental health in Maku. Global J Health Sci. 2015;7(2):379.

32. Commission EE. Towards a European road safety area: policy orientations on road safety 2011-2020. Communication from the Commission to the European Parliament, the Council, the European Economic and Social Committee and the Committee of the Regions, COM (2010). 2010;389.

33. Wismans J, Skogsmo I, Nilsson-Ehle A, Lie A, Thynell M, Lindberg G. Commentary: status of road safety in Asia. Traffic Inj Prev. 2016;17(3):217-25.

34. WHO. The world health report 2001. Implementing specific interventions to prevent road traffic injuries. violence and injury prevention for road traffic injury. Geneva: World Health Organization.

35. Mark Lee S, Al-Mansour Al. Development of a new traffic safety education material for the future drivers in the Kingdom of Saudi Arabia. J King Saud Univ - Eng Sci. 2020 2020/01/01/;32(1):19-26.

36. Peden M. Road safety in 10 countries: BMJ Publishing Group Ltd; 2010.

37. Mütze F, De Dobbeleer W. The status of traffic safety and mobility education in Europe. 'https://etsceu/the-status--of-traffic-safety-and-mobility- education-in-europe/. 2019;European Transport Safety Council (ETSC). Brussels.

38. Hyder AA, Paichadze N, Toroyan T, Peden MM. Monitoring the decade of action for global road safety 2011-2020: an update. Glob Public Health. 2017;12(12):1492-505.

39. Jamaludin S, Othman N, Low S, Wong S. Effective instructional method of road safety education: a review. 2016.

40. Sadeghi-Bazargani H, Somi M-H, Golestani M, Amiri M, Ghaffarifar S, Aslanabadi S, et al. Developing and preliminary evaluation of a general academic course on traffic health and safety. Res Dev Med Educ. 2018;7(1): $21-5$.

41. Al Turki YA. How can Saudi Arabia use the decade of action for road safety to catalyse road traffic injury prevention policy and interventions? Int J Inj Control Saf Promot. 2014;21(4):397-402.

42. Stevenson $M$, Thompson J. On the road to prevention: road injury and health promotion. Health Promot J Aust. 2014;25(1):4-7.

43. Topolšek $D$, Babić $D$, Fiolić $M$. The effect of road safety education on the relationship between Driver's errors, violations and accidents: Slovenian case study. Eur Transp Res Rev. 2019;11(1):18.

44. Dragutinovic N, Twisk DAM. The effectiveness of road safety education, a literature review. Technical Report No. R-2006-6. SWOV. Institute for Road Safety Research: Leidschendam, The Netherlands, 2006.

\section{Publisher's Note}

Springer Nature remains neutral with regard to jurisdictional claims in published maps and institutional affiliations.
Ready to submit your research? Choose BMC and benefit from:

- fast, convenient online submission

- thorough peer review by experienced researchers in your field

- rapid publication on acceptance

- support for research data, including large and complex data types

- gold Open Access which fosters wider collaboration and increased citations

- maximum visibility for your research: over $100 \mathrm{M}$ website views per year

At BMC, research is always in progress.

Learn more biomedcentral.com/submissions 